\title{
Red Cell Survival During Ramaḍān Fasting
}

Mohammed Salim Al-Hadramy, M.R.C.P., Joseph Acquaye, F.W.A.C.P., Awad Omer, F.R.C. Path, F.R.C.E. Jeddah, Saudi Arabia

DOI: http://dx.doi.org/10.5915/22-1-13520

\begin{abstract}
Fasting the month of Ramadãn is a unique metabolic exercise which has not been studied properly. We have carried out the first red cell survival study during Ramadän fasting. The subjects were six normal adults and three adult patients with sickle cell disease. All the subjects fasted the whole month. The ranges of ${ }^{51} \mathrm{CrT50}$ for normal subjects and patients were $25-40$ and 10-12.5 days respectively. These are similar to the published values for non-fasting subjects. We did not note any harmful effects from Ramadān fasting on the red cell survival in our subjects to justify giving advice against fasting.
\end{abstract}

Key words: Ramadän, fasting, sickle cell, chromium

\section{Introduction}

Fasting the month of Ramadān is obligatory for all adult Muslims, as it is one of the five Pillars of Islam.

"Ye who believe! Fasting is prescribed to you as it was prescribed to those before you, that ye may (learn) self-restraint. ${ }^{\prime}$

All adult Muslims fast every year from dawn until sunset during the month of Ramadān, which varies from 29 to 30 days. During the fasting hours, Muslims refrain from eating, drinking and smoking, and maintain sexual continence. At night, none of the above things are prohibited. However, if a person is ill, or if fasting produces a deleterious effect on their health, they are exempt from fasting.

"But if any of you is ill, or on a journey, the prescribed number (should be made up) from days later. ${ }^{2}$

From the Department of Medicine King Abdulaziz University Hospital Jeddah 21452, Saudi Arabia

Reprint Requests: Dr. Mohamed Salim Al-Hadramy

Department of Medicine

King Abdulaziz University Hospital

P.O. Box 6615 , Jeddah 21452

Saudi Arabia
This has to be determined by the person's own experience and by advice from a doctor.

Few reports have described biochemical and endocrine changes in blood ${ }^{3-8}$ and fluid and electrolyte balance' during Ramadān fasting. In one study ${ }^{10}$ it was claimed that there may be a decrease in the mean red cell survival time as a result of Ramaḍann fasting. This was based on the observation of a rise in the mean cell volume and a non-significant rise in the serum iron, although the hemoglobin and the hematocrit were higher during Ramaḍān than the levels were beforehand. Our study was designed to verify this, and to discover whether Ramaḍan fasting has any deleterious effects on hematological values, including red cell survival, in normal subjects as well as sickle cell anemia patients. To our knowledge, this is the first study of red cell survival during Ramaḍān fasting.

\section{Methods and subjects}

Nine adult subjects participated in this study including three healthy males, three healthy females and three patients with sickle cell anemia (two females, one male). The range of the ages was 20 to 45 years.

Females were selected based on menstrual cycle such that none had a menstrual period during the time of the red cell survival study (15 days). All subjects maintained the Muslim fasting during 


\section{Red Blood Cell Count $\times 10^{12 / L}$}

Hemoglobin GMS $\%$

Erythrocyte

Survival

Subjects

Before

Day 10

Day 25

Before

Day 10

${ }^{51}$ CrT50

Fasting

Fasting

Fasting

Fasting

Fasting

Day 25

(Days)

\section{Normal Females}

Control \#1

Control \#2

Control \#3

4.64

4.28

5.17

\subsection{3}

4.11

4.98

5.33

4.32

5.22

Normal Males

Control \#4

Control \#5

Control \#6

5.25

4.82

5.59

4.71

5.42

4.61

5.19

5.33

5.22
14.0

13.1

12.5

15.6

14.9

15.8
14.8

12.8

12.8

16.2

14.9

16.2
14.2

12.9

12.7

15.8

14.2

15.4
28.0

40.0

37.0

29.0

33.0

25.0

Female Sicklers

Patient \#1

2.12

2.22

2.92

3.10

2.30

2.96

7.8

7.2

9.7

8.0

10.0

9.5

9.4

12.5

Male Sickler

Patient \#3

4.18

3.96

3.56

8.7

8.4

7.5

11.0

Ramaḍān. Average fasting time was about 15 hours.

The sickle cell anemia patients had been followed for some time in our hospital. Diagnosis in each was confirmed by family studies after finding hemolytic anemia and a single major band at $\mathrm{HbS}$ position on electrophoresis. Blood for complete blood count (CBC) was collected in disposable sequestrine bottles. CBC was done in a Coulter Counter Model S + II. Reticulocyte count was done using standard techniques. ${ }^{11}$ All investigations were done immediately before the month of Ramadān, then repeated on days 10,19 and 25 of that month.

\section{Red Cell Survival Studies}

In order to allow time for the effects of the fasting, red cell survival studies begun on day 10 of Ramadān. The method used is based on that recommended by the International Committee for Standardization in Haematology, ${ }^{12}$ with slight modification to suit our study. Ten milliliters of blood were drawn and added to $1.5 \mathrm{ml}$ of acid citrate dextrose (ACD) solution in a sterile bottle. After centrifugation and removal of most of the plasma, $50 \mathrm{UCi}$ of radioactive Sodium Chromate $\left({ }^{51} \mathrm{Cr}\right)$ were added and the contents incubated at $37^{\circ} \mathrm{C}$ for 30 minutes. The red cells were then washed twice in sterile saline, after which $10 \mathrm{ml}$ were slowly administered to the subject intravenously. One milliliter of the remaining red cells was diluted to $100 \mathrm{ml}$ in distilled water, for use as a standard. Five milliliters of blood were drawn from a vein in the opposite arm 30 minutes after re-injecting the red cells (day 10). Subjects were then bled after 24 hours (day 1). Three specimens were collected between day 2 and day 7 , and then every third day up to day 15 of the study (day 25 of Ramaḍān).

Although this covered the disappearance of $50 \%$ radioactivity in sickle cell patients, it was unfortunately not possible to attain the same with normal controls due to the advent of Ramaḍan holidays, four days before the end of fasting. All samples were kept frozen at $-30^{\circ} \mathrm{C}$. Each set of samples was then thawed and counted on the same day in a Beckmann 4 Alpha Counter. The radioactivity of the day 0 samples was taken as $100 \%$ and subsequent counts calculated as a percentage of that. Results were plotted on semilogrithmic graph paper; the line extrapolated and ${ }^{51} \mathrm{CrT} 50$ were taken as the time when $50 \%$ radioactivity had disappeared.

\section{Results}

All subjects completed the fasting of Ramadān without any significant complications. One female sickle cell patient had marked low back pain on day 14 of fasting. The male patient had pain in the left hip and ankles on day 15 of fasting. No significant changes were noted in the reticulocyte count, MCV, $\mathrm{MCH}$ or $\mathrm{MCHC}$. The results are summarized in Table 1.

\section{Discussion}

This study has shown that there were no significant ill effects on our fasting subjects. In particular, none 
of the sickle cell patients had to break their fasting. The range of ${ }^{51} \mathrm{CrT} 50$ for our normal subjects during Ramadān was 25-40 days, which fits with the normal value in non-fasting normal subjects. ${ }^{11}$ The range for sickle cell patients was 10-12.5 days. This lies within the expected range for non-fasting sickle cell patients which is quoted as $8-12$ days. ${ }^{13}$ These results show that there is no reduction in red cell survival during Ramadān fasting.

The case of the male sickle cell patient is worth discussing in detail. Although his ${ }^{51}$ CrT50 was 11 days, his hemoglobin dropped from $8.7 \mathrm{~g} / \mathrm{dl}$ before Ramadān to $7.5 \mathrm{~g} / \mathrm{dl}$ on day 25 of the month. His reticulocyte count was $4 \%$ and $4.5 \%$ on those two days, respectively. His hemoglobin on day 19 of Ramad̄an was $8.6 \mathrm{~g} / \mathrm{dl}$ and the reticulocyte count was $4.5 \%$. The pain he experienced on day 15 of fasting was associated neither with fever nor with an increase in the intensity of jaundice or reticulocyte count. However, we could not exclude a mild aplastic reaction of the bone marrow as a cause for the later drop in hemoglobin, especially as the reticulocyte count during the time did not rise.

Although we could not document any significant deleterious effect of fasting in our normal subjects, more studies on large numbers of patients are needed before proper advice can be given to patients during Ramaḍān. Meanwhile, every case has to be assessed individually and, if the patient experiences any significant morbidity, he should be exempted from fasting.

\section{Acknowledgement}

This study was supported by a grant from the King Fahd Medical Research Centre, King Abdulaziz University, Jeddah.

\section{References}

1. Glorious Qur'ān, Chapter II, Verse 183.
2. Glorious Qur'ān, Chapter II, Verse 184.

3. Fedail SS, et al: Changes in certain blood constituents during Ramadan. Am J Clin Nutr A 1982; 36:350-353.

4. Gumaa KA, et al: The effects of fasting in Ramadān 1. Serum uric acid and lipid concentration. Br J Nutr 1978; 40:573-581.

5. Prentice AM, et al: Metabolic consequences of fasting during Ramadān in pregnant and lactating women. Hum Nutr: Clin Nutr 1983; 37C:283-294.

6. Angel J, Schwartz NE: Metabolic changes from decreased meal frequency in adult male Muslims during the Ramaḍann fast. Nutr Rep Int 1975; 11:29-38.

7. Al-Hadramy MS, Zawawi TH, Abdelwahad SM: Altered cortisol levels in relation to Ramadān. Eur J Clin Nutr 1988; 359-362.

8. Hallack MH, Nomani MZ: Body weight loss and changes in blood lipid levels in normal men on hypocaloric diets during Ramadān fasting. Am J Clin Nutr 1988; 48:1197-1210.

9. Gumaa KA, et al: The effects of fasting in Ramadān. 2. Fluid and electrolyte balance. $\mathrm{Br} \mathrm{J}$ Nutr 1978; 40:583-589.

10. Scott T: The effects of the Muslim fast of Ramaḍān on routine laboratory investigations. King Abdulaziz Medical Journal, 1981; Dec. 1 (4):23-35.

11. Dacie JV, Lewis SM: Practical Haematology. London: Churchill Livingstone, 1975.

12. International Committee for Standardization in Haematology. A report on diagnostic applications of radioisotopes in haematology. Recommended methods for radioisotope red-cell survival studies. Br J Haematol, 1971; 241-250.

13. Postgraduate Haematology. Hoffbrand AV, Lewis SM, eds. London: William Heinemann Medical Books Ltd., 1981. 